\title{
Hypomorphic variants of cationic amino acid transporter 3 in males with autism spectrum disorders
}

\author{
Caroline Nava $^{1,2,3,4,5} \cdot$ Johanna Rupp $^{6} \cdot$ Jean-Paul Boissel $^{6} \cdot$ Cyril Mignot $^{5,7,8,9}$. \\ Agnès Rastetter ${ }^{1,2,3,4}$ - Claire Amiet ${ }^{10}$ - Aurélia Jacquette ${ }^{5,7,8}$ - Céline Dupuits ${ }^{1,2,3,4}$. \\ Delphine Bouteiller ${ }^{1,2,3,4} \cdot$ Boris Keren $^{5} \cdot$ Merle Ruberg $^{1,2,3,4}$ - Anne Faudet ${ }^{5}$. \\ Diane Doummar ${ }^{9} \cdot$ Anne Philippe $^{10} \cdot$ Didier Périsse $^{10,11}$ - Claudine Laurent ${ }^{1,2,3,4,10}$. \\ Nicolas Lebrun ${ }^{12}$ - Vincent Guillemot ${ }^{13}$ - Jamel Chelly ${ }^{12}$ - David Cohen ${ }^{10,14}$. \\ Delphine Héron ${ }^{5,7,8,9} \cdot$ Alexis Brice ${ }^{1,2,3,4,5} \cdot$ Ellen I. Closs $^{6} \cdot$ Christel Depienne $^{1,2,3,4,5}$
}

Received: 23 June 2015 / Accepted: 14 July 2015 / Published online: 28 July 2015

(C) The Author(s) 2015. This article is published with open access at Springerlink.com

\begin{abstract}
Cationic amino acid transporters (CATs) mediate the entry of L-type cationic amino acids (arginine, ornithine and lysine) into the cells including neurons. CAT-3, encoded by the SLC7A3 gene on chromosome X, is one of the three CATs present in the human genome, with selective expression in brain. $S L C 7 A 3$ is highly intolerant to variation in humans, as attested by the low frequency of deleterious variants in available databases, but the impact on variants in this gene in humans remains undefined. In this study, we identified a missense variant in SLC7A3,
\end{abstract}

A. Brice, E. I. Closs and C. Depienne are joint last authors.

Electronic supplementary material The online version of this article (doi:10.1007/s00726-015-2057-3) contains supplementary material, which is available to authorized users.

Christel Depienne

christel.depienne@upmc.fr

1 Sorbonne Universités, UPMC Univ Paris 06, UMR S 1127, ICM, 75013 Paris, France

2 INSERM, U 1127, 75013 Paris, France

3 CNRS, UMR 7225, 75013 Paris, France

4 Institut du cerveau et de la moelle épinière (ICM), 75013 Paris, France

5 Département de Génétique et de Cytogénétique, Hôpital de la Pitié-Salpêtrière, AP-HP, 75013 Paris, France

6 Department of Pharmacology, University Medical Center of the Johannes Gutenberg University, Mainz, Germany

7 Centre de Référence "déficiences intellectuelles de causes rares", Paris, France

8 Groupe de Recherche Clinique (GRC) "déficience intellectuelle et autisme" UPMC, Paris, France

9 Service de neuropédiatrie, Hôpital Trousseau, AP-HP, Paris, France encoding the CAT-3 cationic amino acid transporter, on chromosome $\mathrm{X}$ by exome sequencing in two brothers with autism spectrum disorder (ASD). We then sequenced the SLC7A3 coding sequence in 148 male patients with ASD and identified three additional rare missense variants in unrelated patients. Functional analyses of the mutant transporters showed that two of the four identified variants cause severe or moderate loss of CAT-3 function due to altered protein stability or abnormal trafficking to the plasma membrane. The patient with the most deleterious SLC7A3 variant had high-functioning autism and epilepsy, and also carries a de novo 16p11.2 duplication possibly contributing to his phenotype. This study shows that rare hypomorphic variants of $S L C 7 A 3$ exist in male individuals and suggest that $S L C 7 A 3$ variants possibly contribute to the etiology

10 Service de psychiatrie de l'enfant et de l'adolescent, Hôpital Pitié-Salpêtrière, AP-HP, 75013 Paris, France

11 Centre Diagnostic Autisme de l'Hôpital Pitié-Salpêtrière, 75013 Paris, France

12 Institut Cochin, Inserm U567, UMR 8104, Université René Descartes, Paris 5, France

13 Bioinformatics and Biostatistics Core Facility (iCONICS), Institut du cerveau et de la moelle épinière (ICM), Paris, France

14 Institut des Systèmes Intelligents et Robotiques, CNRS UMR 7222, UPMC-Paris-6, Paris, France 
of ASD in male subjects in association with other genetic factors.

Keywords Cationic amino acid transporter - Autism spectrum disorders $\cdot$ Exome sequencing $\cdot$ Chromosome $\mathrm{X}$. Oligogenism

$\begin{array}{ll}\text { Abbreviations } \\ \text { ASD } & \text { Autism spectrum disorders } \\ \text { CAT } & \text { Cationic amino acid transporter } \\ \text { CNV } & \text { Copy number variants } \\ \text { LOH } & \text { Loss of heterozygosity } \\ \text { MAF } & \text { Minor allele frequency } \\ \text { mTOR } & \text { Mammalian target of rapamycin } \\ \text { NO } & \text { Nitric oxide }\end{array}$

\section{Introduction}

The main function of cationic amino acid transporters (CAT) is to mediate the entry of L-type cationic amino acids (i.e., L-arginine, L-ornithine and L-lysine) into many different cell types including neurons (Closs et al. 2006; Jager et al. 2013). Their function is crucial since lysine and arginine, under certain conditions, are essential amino acids that are derived exclusively from the degradation of ingested nutrients. The CAT family comprises three different genes: SLC7A1/CAT-1 on chromosome 13, SLC7A2/ CAT-2 on chromosome 8, and SLC7A3/CAT-3 on chromosome X. All three transporters have different and complementary tissue localizations, making each of them necessary for life and normal health. CAT-3 is selectively expressed in brain in rodents (Hosokawa et al. 1997; Ito and Groudine 1997). In neurons, CAT-3 responds to NMDA receptor activation and regulates the mammalian target of rapamycin (mTOR) signaling pathway, which has a central role in neuronal development and plasticity, through arginine availability (Huang et al. 2007).

Autism spectrum disorders (ASD) are neurodevelopmental disorders characterized by impaired social interactions and communication, restricted interests and repetitive or stereotyped behaviors (Lai et al. 2014). Intellectual disability (ID) is a frequent comorbidity of ASD, present in more than half of ASD subjects (Srivastava and Schwartz 2014; Tuchman and Rapin 2002; Amiet et al. 2008). ASD are highly genetically determined, but the genetic factors involved in these disorders are extremely heterogeneous and have proven difficult to identify (Betancur 2011; Huguet et al. 2013; Jeste and Geschwind 2014), and, in spite of the acceleration of gene identification due to technological advances, a genetic cause is still found in a minority of ASD cases. De novo or inherited copy number variants $(\mathrm{CNV})$, strongly associated with autism and probably conferring high susceptibility to ASD, have been identified in 2-10\% of patients (Girirajan et al. 2013; Sanders et al. 2011; Glessner et al. 2009; Bucan et al. 2009; Pinto et al. 2010; Huguet et al. 2013). Additional copies of the 15q11-q13 region or an abnormal number of copies in the $16 \mathrm{p} 11.2$ region are examples of recurrent $\mathrm{CNV}$ s found in ASD (Sanders et al. 2011; Depienne et al. 2009; Weiss et al. 2008; Kumar et al. 2008; Nava et al. 2014b; Levy et al. 2011). More recently, exome sequencing of parentoffspring trios has shown that de novo point mutations contribute to ASD in 10-30\% of sporadic patients (Murdoch and State 2013; Krumm et al. 2014; O'Roak et al. 2011, 2012; Sanders et al. 2012; Neale et al. 2012; Iossifov et al. 2012, 2014). These studies predicted that ASD could result from genetic abnormalities in several hundreds of different genes, many of which are, nonetheless, interconnected or part of common functional pathways (Neale et al. 2012; O'Roak et al. 2012; Sanders et al. 2012; Iossifov et al. 2012; Gilman et al. 2011). Examples of pathways repeatedly involved in ASD include: synaptic function, illustrated by mutations in SHANK1-3 scaffolding proteins, neuroligins, neurexins, contactins and contactin-associated proteins encoding genes; the mTOR pathway, illustrated by mutations in TSC1/TSC2 or PTEN that cause syndromic forms of ASD; chromatin remodeling; and Wnt signaling (Krumm et al. 2014; Jeste and Geschwind 2014; Huguet et al. 2013). An excess of males (4 affected males for one affected female) is typically observed in ASD (Schaafsma and Pfaff 2014; Werling and Geschwind 2013), suggesting that genes located on sex chromosomes contribute to the etiology of the disorders, or that the penetrance of autistic traits depends on sex determinants (Werling and Geschwind 2013).

In this study, we used exome sequencing to identify genetic factors contributing to ASD in a family comprising two affected brothers. The identification of a missense variant in SLC7A3 on chromosome $\mathrm{X}$, shared by the two brothers, prompted us to investigate the consequences and phenotypic contribution of variants in this gene in male individuals.

\section{Materials and methods}

\section{Subjects}

Exome sequencing was performed in Family 505, originating from Morocco, and comprising two affected brothers born of consanguineous parents (Fig. 1a). The proband (01) had a normal motor development but presented with language delay. He was diagnosed with autistic spectrum disorder associated with moderate intellectual disability. $\mathrm{He}$ had obsessive-compulsive behaviors, phobias and sleeping 
a

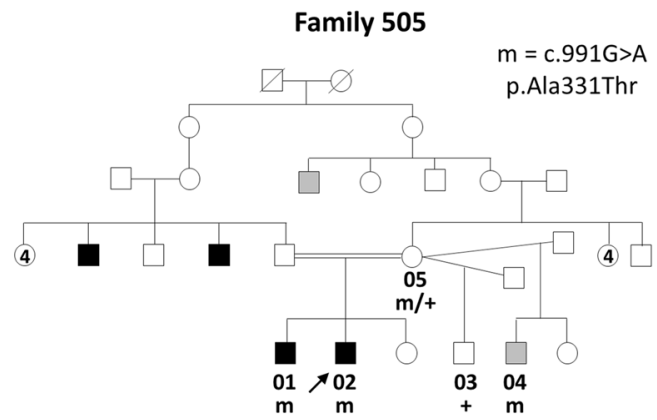

Family 885

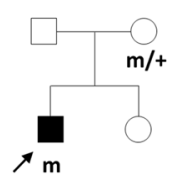

$m=c .1289 A>G$

p.Tyr430Cys

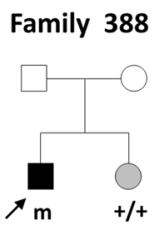

$\mathrm{m}=\mathrm{c} .1766 \mathrm{G}>\mathrm{C}$

p.Ser589Thr b

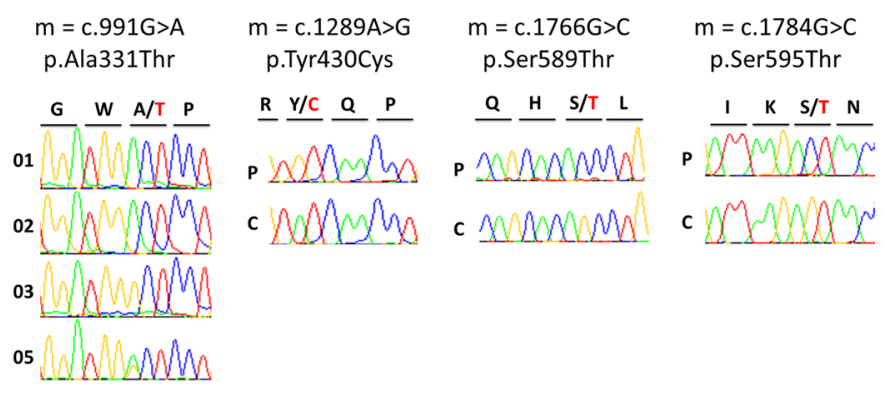

d

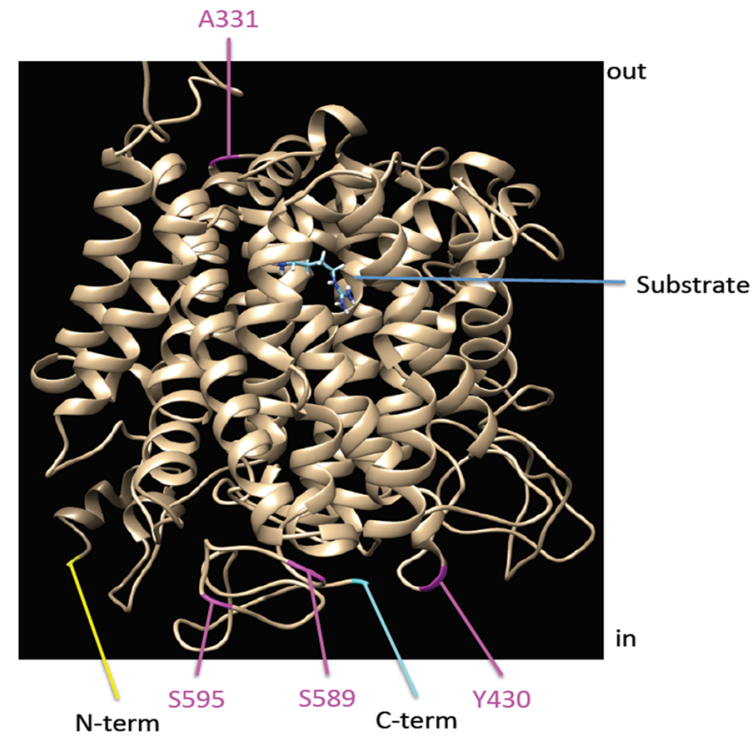

state in the affected individuals of Families 505 (01, 02), 885, 388, $962(\mathrm{P})$, in the heterozygous state in the mother of Family 505 (05) and their absence in an unaffected brother in Family 505 (03) and controls (C). c Alignment of the regions flanking the SLC7A3/CAT-3 missense variant in orthologous proteins showing the conservation of the altered amino acids. d Schematic model of the CAT- 3 protein showing the putative location of the amino acid residues altered by the variants

The study was approved by the local Institutional Review Board (Comité de Protection des Personnes, Hôpital Pitié-Salpêtrière, Paris, France). Informed written consent was obtained from each subject or his parents or legal representatives before blood sampling. Genomic DNA of patients and relatives was extracted from blood cells using standard phenol-chloroform procedures. Cerebrospinal fluid (CSF) sampling in subject 02 of family 505 was performed in a diagnostic context.

\section{SNP array analysis}

The affected brothers and their healthy sister were genotyped using cytoSNP-12 microarrays (Illumina, San Diego, CA). Automated Illumina microarray experiments were performed as previously described (Nava et al. 2014b). Image acquisition was performed using an iScan System of ASD patients were sporadic cases. 
(Illumina). Image analysis and automated CNV calling was performed using GenomeStudio v2011.1 and CNVPartition v3.1.6 with the default confidence threshold of 35. Loss of heterozygosity $(\mathrm{LOH})$ regions with a size $>2 \mathrm{Mb}$ were determined using CNVPartition v3.1.6.

\section{Exome sequencing}

The exome of the two affected brothers in family 505 and their unaffected mother was sequenced by Integragen SA (Evry), as previously described (Nava et al. 2014a). Rare coding variants or variants predicted to alter consensus splice sites with a read depth $\geq 10$ shared by the two affected brothers were listed using the ERIS interface (Integragen). Rare variants were defined by a minor allele frequency (MAF) $\leq 1 \%$ in Hapmap, 1000 Genomes, Exome variant server, and in an in-house Integragen exome database. Further analysis of exome data focused on the search for homozygous mutations located in identical-by-descent regions or hemizygous variants on chromosome X. Possibly deleterious variants were defined as indels introducing frameshifts or in-frame insertions or deletions, nonsense or splice-site mutations, mutations altering start or termination codons, or nonsynonymous variants predicted to be possibly deleterious by at least one of three prediction algorithms (see bioinformatics analyses).

\section{Sanger sequencing}

Specific primer pairs were designed to confirm the variants detected by exome sequencing in $S L C 7 A 3, C C D C 120$, $A R A F, F A M 123 B$ and SLC9A6 on chromosome $\mathrm{X}$, and SCN2A, MAS1L, FOXP2, ROBO4, NOS1, PARP4, CACNAIH, ZSCAN10, TRAP1 and TMPRSS9 on autosomal chromosomes and to study their segregation in relatives. The exons and intron-exon junctions of SLC7A3 (NM_001048164.2) were amplified and analyzed using 11 primer pairs (Table S1). Forward and reverse sequence reactions were performed with the Big Dye Terminator Cycle Sequencing Ready Reaction Kit (Applied Biosystems, Foster City, California). G50-purified sequence products were run on an $\mathrm{ABI} 3730$ automated sequencer (Applied Biosystems); the data were analyzed with Seqscape v2.6 software (Applied Biosystems).

\section{Bioinformatic and statistical analyses}

Missense variants were assessed in silico for possible pathogenicity using Alamut 2.3 (Biointeractive Software, France), PolyPhen-2 (http://genetics.bwh.harvard.edu/ pph2), SIFT (http://sift.bii.a-star.edu.sg), and Mutation Taster (www.mutationtaster.org). A three-dimensional model of the first predicted 10 TMDs of hCAT- 3 was generated as previously described for hCAT-2A (Beyer et al. 2013). Comparison of the number of $S L C 7 A 3$ variants in male ASD patients versus males of the ESP population ( $n=2443$, Exome variant server, http://evs.gs.washington. edu/EVS/) or male control subjects included in the IPDGC study $(n=338)$ was performed with the Fisher's Exact Test. The probability to identify at least $\mathrm{n}$ variants in $S L C 7 A 3$ in the tested patient population was calculated based on the frequency of SLC7A3 rare variants in the ESP and IPDGC populations using a binomial distribution.

\section{Immunofluorescence staining and isolation of plasma membrane proteins}

Missense variants identified in autistic patients were introduced into plasmids expressing the human CAT-3 cDNA fused to the Green Fluorescent protein (GFP). Cos7 cells were transiently co-transfected with $5 \mu \mathrm{g}$ of WT or mutant CAT-3 expression plasmids using a neon electroporation system (Invitrogen). Cells were fixed with $4 \%$ paraformaldehyde (PFA) $24 \mathrm{~h}$ after transfection, permeabilized with $0.1 \%$ Triton X-100, and incubated with anti-calreticulin (ER marker, Abcam, ab2907, 1:1000) for at least $2 \mathrm{~h}$ at room temperature. The signal was revealed by incubation with a Cy3-coupled sheep anti-mouse IgG antibody (Sigma, 1:1000) for $1 \mathrm{~h}$ at room temperature. Nuclei were stained with Hoechst (1:1000). Fluorescent images were acquired with a confocal system (Leica SP2 AOBS AOTF).

Proteins present at the plasma membrane of Cos7 transfected cells were isolated following surface biotinylation of living Cos7 cells with the Cell Surface Protein Isolation Kit (Pierce), following the manufacturer's recommendations. Proteins were resolved by SDS-PAGE on 4-12 \% gradient gels (Invitrogen) and electrotransferred onto nitrocellulose membranes. CAT-3 was probed with an anti-GFP antibody (monoclonal mouse anti-GFP antibody, \#11814460001, Roche, 1:4000), and the signal was revealed by enhanced chemiluminescence (Pierce). The membranes were subsequently probed with an anti-Tom20 (BD Biosciences $612278,1: 1000)$ antibody to confirm plasma membrane enrichment, and with an anti-Flotillin-1 (BD Biosciences $610820,1: 1000)$ antibody for normalization. The ImageJ program (http://rsb.info.nih.gov/ij/) was used for signal quantification. Independent measures from at least 3 different experiments were analyzed with the Mann-Whitney test.

\section{Transporter expression and transport studies in Xenopus laevis oocytes}

cRNA was prepared by in vitro transcription from the SP6 promoter of CAT-3-GFP-pSP64T (mMessage mMachine in vitro transcription kit, Ambion Inc, Austin, TX, USA) 
(Vekony et al. 2001). Seventeen nanograms of human CAT-3-GFP cRNA were injected into each $X$. laevis oocyte (Dumont stages V-VI). Noninjected oocytes were used as controls. Arginine uptake was determined 3 days after injection of cRNA as previously described (Closs et al. 1997). Briefly, oocytes were washed in uptake solution $\left(100 \mathrm{mM} \mathrm{NaCl}, 2 \mathrm{mM} \mathrm{KCl}, 1 \mathrm{mM} \mathrm{MgCl}, 1 \mathrm{mM} \mathrm{CaCl}_{2}\right.$, $5 \mathrm{mM}$ HEPES, $5 \mathrm{mM}$ Tris, pH 7.5) containing $1 \mathrm{mM}$ unlabeled arginine then transferred to the same solution supplemented with $0.37 \mathrm{MBq} / \mathrm{ml} \mathrm{L-}\left[2,3,4-{ }^{3} \mathrm{H}\right]$ arginine monohydrochloride (MP), $1.59 \mathrm{TBq} / \mathrm{mmol}$. After incubation for $15 \mathrm{~min}$ at $20{ }^{\circ} \mathrm{C}$, the oocytes were washed four times in ice-cold uptake solution and solubilized individually in $2 \%$ sodium dodecyl sulfate (SDS). The incorporated radioactivity was quantified in a liquid scintillation counter (TriCarb 2810 TR, Perkin Elmer).

\section{Oocyte lysates and biotinylation of cell surface proteins}

All steps were performed at $4{ }^{\circ} \mathrm{C}$, as previously described (Beyer et al. 2013). Briefly, ten oocytes were each incubated for 30 min with membrane impermeable EZ-Link ${ }^{\mathrm{TM}}$ SulfoNHS-SS-Biotin (Sulfosuccinimidyl-2-(biotinoamido)ethyl1,3-dithiopropionate, Thermo Fisher Scientific Inc., Rockford; $1 \mathrm{mg} / \mathrm{ml}$ in $\mathrm{PBS}_{\text {mod }} / \mathrm{CM}$ ). The biotinylation reaction was stopped by incubating the oocytes in $\mathrm{PBS}_{\text {mod }}$ containing $50 \mathrm{mM} \mathrm{NH} \mathrm{Nl}_{4} \mathrm{Cor} 10 \mathrm{~min}$. After lysis in $200 \mu \mathrm{l}$ radioimmune precipitation assay buffer (RIPA: $1 \%$ deoxycholate, $1 \%$ Triton X-100, $0.1 \%$ SDS, $150 \mathrm{mM} \mathrm{NaCl}, 2 \mathrm{mM}$ $\mathrm{MgCl}_{2}, 10 \mathrm{mM}$ Tris-HCl pH 7.2) containing protease inhibitors (Complete Mini EDTA-free protease inhibitor tablets, Roche, Basel), an aliquot of each whole oocyte lysate was mixed directly with an equal volume of $2 \times$ sample buffer (125 mM Tris base, $20 \%$ glycerol (v/v), $5 \%$ SDS, $0.001 \%$ bromphenol blue $(\mathrm{m} / \mathrm{v}), 8 \mathrm{M}$ urea, $2 \%$ mercaptoethanol) and incubated for $10 \mathrm{~min}$ at $37{ }^{\circ} \mathrm{C}$. The remaining lysate was incubated overnight with avidin-coated Sepharose beads (NeutrAvidin ${ }^{\circledR}$ UltraLink ${ }^{\circledR}$ Resin, Thermo Fisher Scientific Inc., Rockford) to recover the biotinylated surface proteins. The beads were then washed three times with RIPA containing protease inhibitors (PMSF $200 \mu \mathrm{M}$ ). Biotinylated proteins were released from the beads by incubation in $2 \times$ sample buffer for $10 \mathrm{~min}$ at $37^{\circ} \mathrm{C}$. Oocytes lysates were then separated by 7.5 or $12.5 \%$ SDS-PAGE and tank-blotted onto nitrocellulose membranes, as previously described (Beyer et al. 2013). CAT-3 proteins on the blots were stained by incubation with rabbit polyclonal GFP antibody (Clontech Living colors \#632460, 1:3000) overnight at $4{ }^{\circ} \mathrm{C}$ followed by goat anti-rabbit $\operatorname{IgG}, \mathrm{H} \& \mathrm{~L}$ chain-specific peroxidase conjugate (Calbiochem \#401393, $1: 15,000)$ for $1 \mathrm{~h}$ at room temperature. The blots were then incubated for $1 \mathrm{~min}$ with the chemiluminescence reagent (Western Lightning ${ }^{\circledR}$ ECL-Plus, Perkin Elmer, USA) and exposed to chemiluminescence films (Hyperfilm ECL, GE Healthcare Life Sciences, UK). Signal intensity was quantified using Chemidoc ${ }^{\circledR}$ XRS with Quantity One software (BioRad, Berkeley, USA). For standardization, membranes were stained with a mouse monoclonal anti- $\beta$-tubulin antibody (T 4026, Sigma-Aldrich, Deisenhofen, 1:5000) and a rabbit anti-mouse IgG peroxidase conjugate (A 9044, Sigma-Aldrich, Deisenhofen, 1:5000).

\section{Results}

Family 505 comprises two brothers with ASD born from North African consanguineous parents. To identify variants contributing to ASD, we sequenced the exome of the brothers and their healthy mother (Fig. 1a). The affected brothers and their healthy sister were genotyped, in parallel, using Illumina SNP arrays. No pathogenic CNV were detected by this analysis in the affected sibs. Two LOH regions shared by the affected brothers and absent from their sister, a $2.3 \mathrm{Mb}$ region on chromosome 8 and a $7 \mathrm{Mb}$ region on chromosome 15, containing 28 and 39 genes, were found (Fig. S1 and Table S2). Exome sequencing detected 351 rare variants shared by the affected brothers that altered the coding sequence or consensus splice sites in 329 genes (Table S3). None of the variants was located in LOH regions.

Since two maternal male cousins were reported to have unspecified ID and behavioral disturbances, we decided to focus our study on X-chromosomal variants. Three nonsynonymous variants predicted to be possibly deleterious by at least one prediction tool were located on chromosome X (c.624G > C/p.Gln208His in ARAF, c. $991 \mathrm{G}>\mathrm{A} / \mathrm{p}$. Ala331Thr in SLC7A3, c.1477G > A/p.Ala493Thr in $C C D C 120$ ). Analyses of North African control subjects showed that the frequency of the variants in $A R A F$ and $C C D C 120$ was higher than reported in databases in other populations, making their involvement in the phenotype of the brothers unlikely; the c.991G > A/p.Ala331Thr variant in $S L C 7 A 3$ was not found, however, in 630 controls including 440 North African subjects (Table S4).

We then screened 148 unrelated males with ASD for mutations in exons of $S L C 7 A 3$. We identified three rare hemizygous variants that altered conserved amino acids in three patients (Fig. 1): c.1289A > G/p.Tyr430Cys was identified in a 10-year-old boy with high-functioning autism and epilepsy, whereas c.1766G > C/p.Ser589Thr and c. $1784 \mathrm{G}>\mathrm{C} / \mathrm{p}$.Ser595Thr were identified in patients with ASD and ID.

To investigate the functional consequences of the identified SLC7A3 missense variants, we analyzed the cellular distribution and transport activities of the four mutant CAT-3 transporters. We first compared the subcellular 


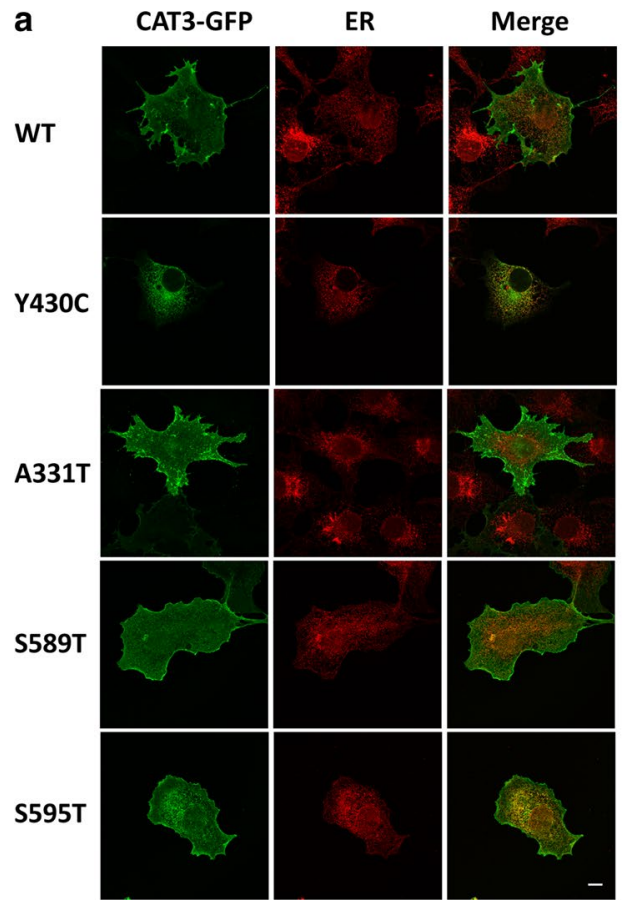

Fig. 2 Subcellular localization and expression of CAT-3 mutants at the plasma membrane in mammalian cells. a Subcellular localization of wild-type and mutant (p.Tyr430Cys, p.Ala331Thr, p.Ser589Thr, p.Ser595Thr) CAT-3 proteins and colocalization with endoplasmic reticulum (ER, marked using anti-calreticulin) observed by confocal microscopy. Scale bar $20 \mu \mathrm{m}$. b Representative western blot of WT and mutant CAT-3 protein expression in whole lysates and plasma

localization of transiently expressed WT and mutant CAT-3 proteins fused to GFP in mammalian Cos7 cells. Distribution of p.Tyr430Cys-CAT-3 appeared to be restricted to the endoplasmic reticulum (ER), whereas WT and other types of mutant CAT-3 were mostly present at the plasma membrane (Fig. 2a). By labeling plasma membrane proteins with biotin on the extracellular face of intact cells, we confirmed that the amount of p.Tyr430Cys-CAT-3 at the plasma membrane, as well as the overall amount of protein, decreased strongly in comparison to WT CAT-3 (Fig. 2b, c). These results suggest that p.Tyr430Cys-CAT-3 is unstable or trapped in the ER where it is degraded.

Further studies in Xenopus laevis oocytes showed that transport activities were reduced in oocytes expressing p.Tyr430Cys and p.Ser589Thr compared to oocytes expressing WT CAT-3 (Fig. 3a). Overall, expression of p.Tyr430Cys and p.Ser589Thr proteins was also reduced. The reduction was more pronounced in the plasma membrane fraction, especially for p.Tyr430Cys (Fig. 3b, c). Altogether, these findings confirmed that two of the four SLC7A3 variants identified had deleterious effects on CAT-3 protein function.

The p.Ala331Thr variant did not alter the cellular distribution of the overexpressed transporter or its transport

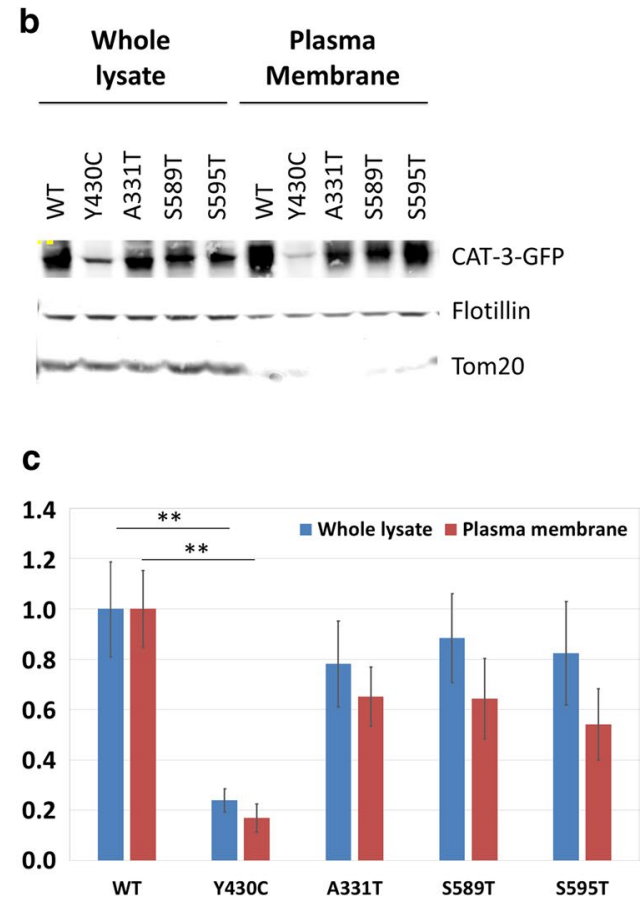

membranes. Flotillin and Tom20 stainings were used to control membrane protein enrichment and normalize protein load, respectively. c Quantification of WT and mutant CAT-3 proteins present in whole lysates and plasma membranes. The values, obtained from at least three different experiments, were compared with the Mann-Whitney test; $* p<0.05$

activity in Xenopus laevis oocytes; we then hypothesized that it may have an effect on CAT-3 that was not detected by the tests we performed. We then assayed arginine, ornithine, and lysine in the CSF of one of the affected brothers with p.Ala331Thr (individual 505-02) sampled in a diagnostic context. Ornithine was slightly decreased in his CSF (5 $\mu \mathrm{mol} / \mathrm{L}$; normal range $7-11 \mu \mathrm{mol} / \mathrm{L})$, suggesting that a misbalance of cationic amino acids possibly results from CAT-3 dysfunction.

CAT-3 has been reported to be specifically expressed in the brain during embryonic development, suggesting that SLC7A3 plays a role for in brain development, but this finding is controversial (Hosokawa et al. 1997, 1999; Ito and Groudine 1997; Closs 2002; Vekony et al. 2001; Jager et al. 2013). We therefore developed a quantitative RT-PCR assay to monitor the expression of CAT-3 in the developing mouse brain. SLC7A3 expression increased from embryonic day 12 (E12) to post-natal day 7 (P7) and declined thereafter; gene expression was strongest in the diencephalon (Fig. S2). In contrast, SLC7A3 was expressed at very low levels in other tissues including heart and liver. These results are consistent with the expression pattern of $S L C 7 A 3$ in the Human Brain Transcriptome Database, which also showed that expression of CAT-3 was higher in the developing human brain. 
Fig. 3 Analysis of WT and mutant CAT-3 transport activity, expression and localization in Xenopus laevis oocytes. a Transport of $100 \mu \mathrm{M}\left[{ }^{3} \mathrm{H}\right]$ L-arginine for $15 \mathrm{~min}$ into oocytes. b Representative Western Blot of WT and mutant CAT-3-EGFP proteins in whole cell lysates and at the plasma membrane. c Quantification of three independent experiments as shown in $\mathbf{b}$, left columns CAT-3 in total cell lysate, right columns in plasma membrane protein fraction
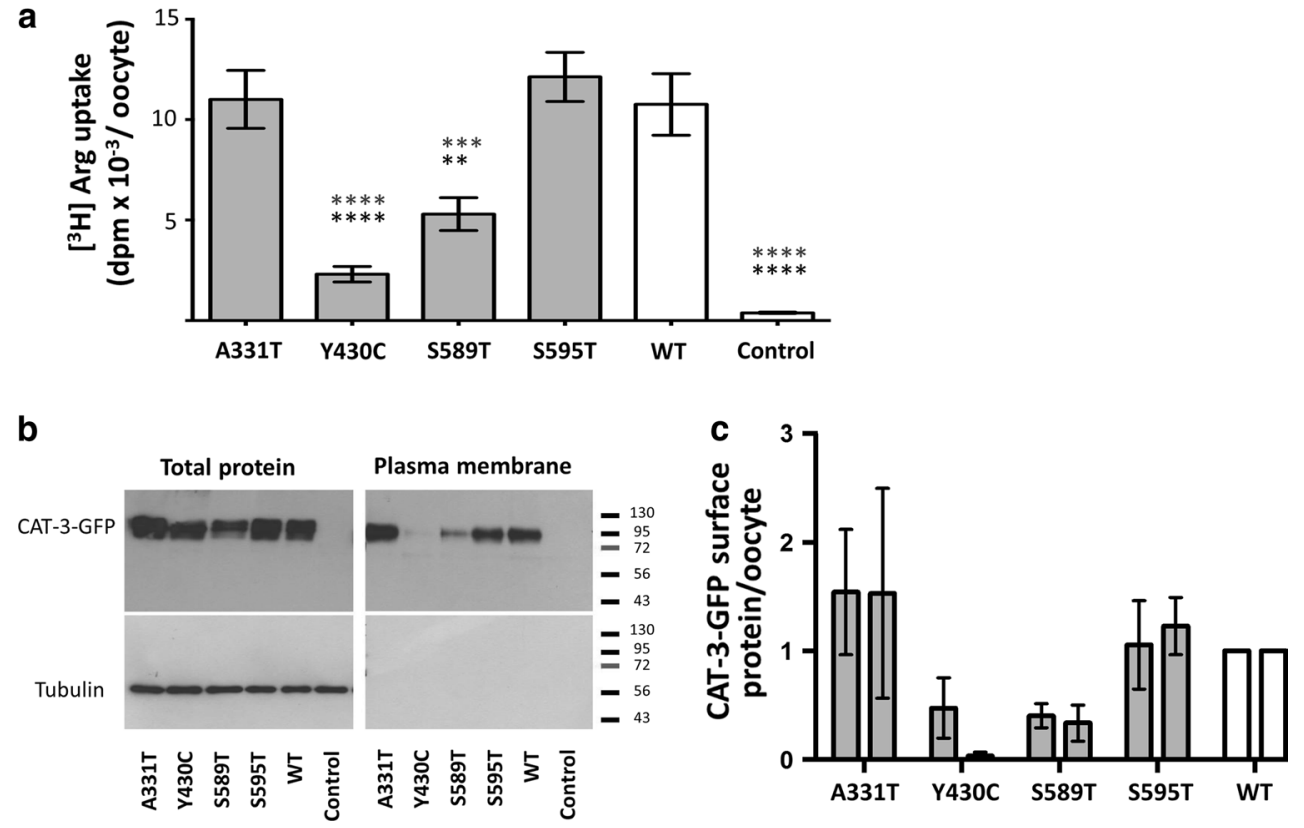

\section{Discussion}

In this study, we identified missense variants in $S L C 7 A 3$, a gene encoding a CAT specifically expressed in the developing brain, in four male subjects with ASD. We showed evidence that two of the identified variants lead to a severe or moderate loss of function of the CAT-3 transporter. This is the first study showing that hypomorphic $S L C 7 A 3$ variants exist in the human male population.

$S L C 7 A 3$ is highly intolerant to variation in humans, as shown by the absence of variants introducing premature termination codons in $~ 61.000$ subjects of the ExAc database (http://exac.broadinstitute.org/gene/ENSG00000165349) and the absence of deletion encompassing SLC7A3 in the DGV database. The absence of variants invalidating SLC7A3 in thousands of control individuals strongly supports the assumption that complete loss of function of CAT-3 is lethal or pathogenic in humans. Constitutive CAT-3 deficiency was previously hypothesized to be lethal at an early embryonic stage in mammals (Closs et al. 2006). Indeed, CAT-1-deficient mice die rapidly after birth (Perkins et al. 1997), and the spared prenatal development of CAT-1-deficient mice is thought to result from the high levels of CAT-3 expressed in embryonic tissues (Ito and Groudine 1997; Nicholson et al. 1998). In contrast, several deletions encompassing SLC7A3 among other genes have been reported in affected females in Decipher. A single male patient with a deletion of $\sim 93 \mathrm{Mb}$ encompassing SLC7A3 (Decipher ID: 284367) is present in Decipher; interestingly, this patient has a syndromic form of autism and developmental delay with additional dysmorphic and neurologic features. In this study, three missense variants were identified out of 148 males with ASD. This proportion ( $2 \%)$ is higher to the frequency of $S L C 7 A 3$ variants observed in the ESP male population $(8 \%, 20 / 2443)$ or in male individuals of the IPDGC study (3\%, 1/338) (Table S5), although the differences are not significant $(p=0.11)$ due to the small number of variant carriers in each population. However, the probability to observe 3 or more variants among 148 individuals by chance based on the frequency of $S L C 7 A 3$ variants in control populations is very low $(p=0.05)$, supporting an excess of $S L C 7 A 3$ variants in patients with ASD. The contribution of variants on chromosome $X$ has been well demonstrated in ID but remains unclear in ASD in spite of an excess of affected males in both disorders. Indeed, the most recent studies on ASD genetic factors using whole exome or genome sequencing have focused on de novo mutations and have neglected the role of variants on chromosome X (Murdoch and State 2013; Krumm et al. 2014; O'Roak et al. 2011, 2012; Sanders et al. 2012; Neale et al. 2012; Iossifov et al. 2012, 2014).

Cationic amino acid supplies in cells, and therefore CAT-mediated transport, are critical for arginine-, lysineand ornithine-dependent metabolic reactions. In particular, arginine is the precursor for the synthesis of nitric oxide (NO), creatine and urea, and ornithine is the starting point for polyamine synthesis. In this context, at least two different consequences of SLC7A3 dysfunction can be hypothesized. On the one hand, since NO is an important cell-cell signaling molecule in the central nervous system (Braissant et al. 1999), reduced availability of arginine in the brain could alter NO synthesis and signaling. In favor of this hypothesis, mice deficient in Nosl, which encodes 
Fig. 4 Schematic diagram showing the possible consequences of $S L C 7 A 3$ dysfunction on the mTOR and NO pathways. Reduced availability of intracellular cationic amino acids, including arginine, could decrease NO synthesis and alter NO-mediated signaling (on the left) or negatively affect the mTOR signaling pathway in neurons (on the right)

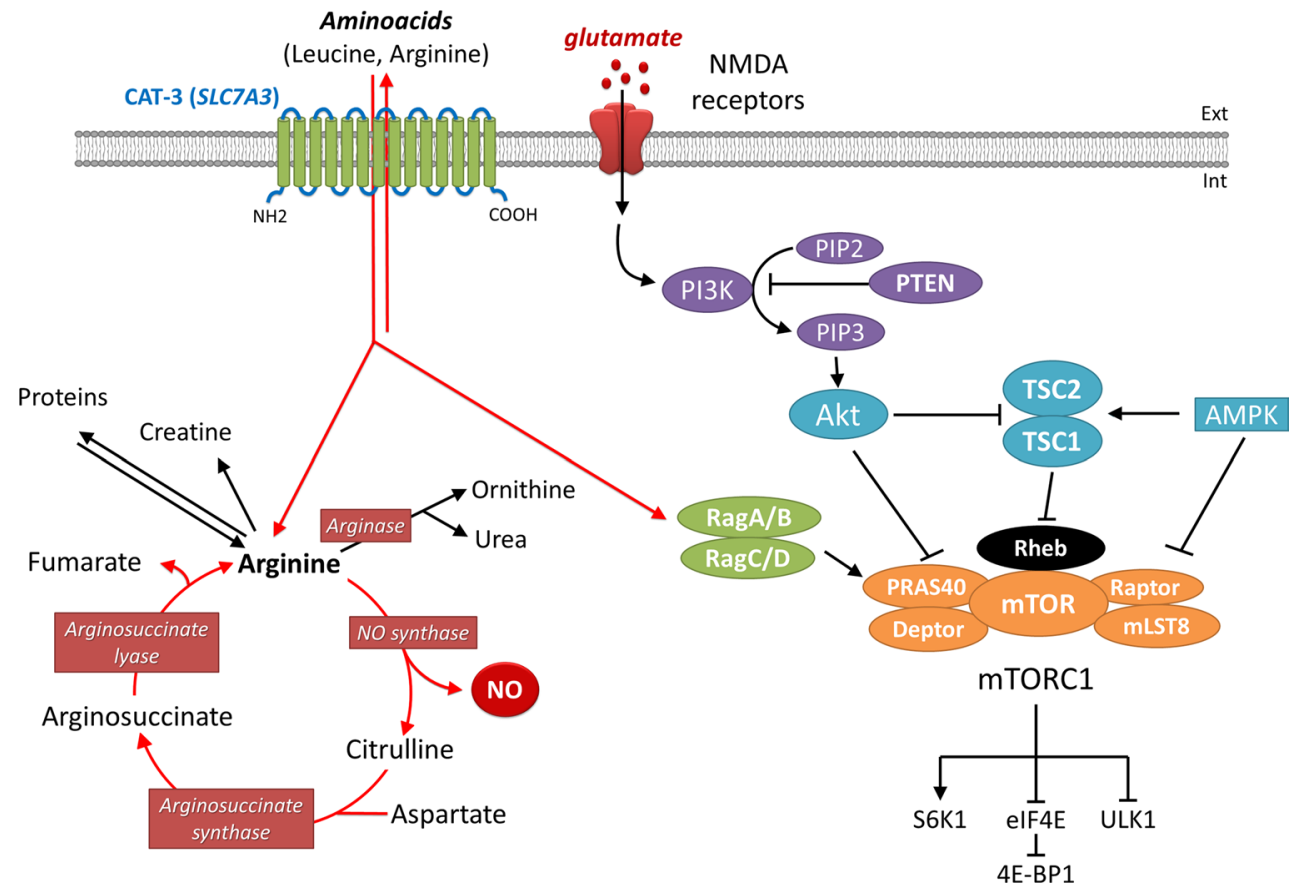

the neuronal NO synthase (nNOS) that converts arginine to NO, display cognitive impairments, aggressivity and hyperactivity as well as additional behavioral abnormalities (Nelson et al. 1995; Weitzdoerfer et al. 2004; Tanda et al. 2009). On the other hand, arginine availability also regulates the mammalian target of rapamycin (mTOR) pathway that controls the survival, differentiation and development of neurons and synaptic plasticity, among other functions (Swiech et al. 2008); reduced CAT-3 activity would therefore be expected to have an impact on the mTOR pathway, which has previously been shown to be impaired in several forms of ASD (Bourgeron 2009; Ehninger and Silva 2011; Veenstra-VanderWeele and Blakely 2012). In particular, CAT-3 variants could modulate the effects of NMDA receptor activation on the mTOR pathway (Fig. 4) (Huang et al. 2007).

Although our results suggest that loss of function of CAT-3 is the main consequence of the identified missense variants, the functional tests performed did not permit to confirm this hypothesis for the p.Ala331Thr, initially identified in Family 505. In spite of the absence of functional effect of this variant on cellular localization and transporter activity, genetic data (absence of this variant from a matched control population, segregation with the disease in the family) support a possible deleterious effect of this variant. In addition, one of the affected brothers had low values of ornithine in his CSF possibly related to a CAT-3 dysfunction. Our hypothesis is therefore that this variant alters an untested function of the CAT-3 transporter. p.Ala331Thr is located in an epitope exposed at the extracellular surface (Fig. 1); it could then alter the interaction of CAT-3 with a putative ligand. Mouse CAT- 1 has been shown to be a receptor for retroviruses (Kim et al. 1991). CAT-3 could be a receptor for a cellular signal during development, although this remains to be demonstrated.

The patient with the most deleterious effect on CAT-3 activity (patient 885, p.Tyr430Cys) had typical autism during childhood but his evolution was favorable and he was diagnosed at 10 years old with high-functioning autism. The preferential expression of CAT-3 during embryogenesis suggests that CAT-3 dysfunction has a negative effect during early brain development. This deficit could therefore partially improve or recover with time due to compensatory expression of other CATs, such as CAT-1, as observed for this patient. This patient also had a de novo duplication on chromosome 16p11.2, previously identified by SNP array (Nava et al. 2014b), that possibly contributes to his phenotype. Recurrent reciprocal deletions and duplications involving the $600 \mathrm{~Kb} 16 \mathrm{p} 11.2$ region were repeatedly associated with ASD and schizophrenia, but are characterized by a great phenotypic variability and low penetrance and do not segregate perfectly with ASD in multiplex families (Sanders et al. 2011; Depienne et al. 2009; Weiss et al. 2008; Kumar et al. 2008; Nava et al. 2014b; Levy et al. 2011). The 16p11.2 duplication by itself could then not be considered as the sole cause of ASD in this patient. We hypothesize that the disorder could then result from the association of p.Tyr430Cys in SLC7A3 and the $16 \mathrm{p} 11.2$ duplication, and eventually other variants in the genome. The possibility of oligogenism, suspected in many cases of ASD, has been supported by several recent studies (Schaaf et al. 2011; Barrett et al. 1999; Chilian et al. 2013; Heil and Schaaf 2013; Jiang et al. 2004; Junaid and Pullarkat 2001; 
Leblond et al. 2012), but identification of the factors interacting together to cause the disorder constitutes a real challenge. Observations on mice suggest that genes functioning in same pathways are more susceptible to display dosagesensitive genetic interactions (Kidd et al. 1999; Hafezparast et al. 2002). Another possibility is that a burden of rare variants in unconnected genes predisposes to autism in an individual (Veltman and Brunner 2010).

Among the variants shared by the affected sibs in Family 505 was a missense variant (NM_000620: p.Arg1369Cys) in NOS1. The two variants in SLC7A3 and NOS1 could have additive effects, decreasing both the availability of arginine and the conversion of arginine to NO in neurons. Among the variants present in the two brothers possibly contributing to autism was a missense variant in $S C N 2 A$, also present in their unaffected sister, as well as a missense variant in CACNAIH gene, encoding a calcium channel, and missense variant in FOXP2, encoding a forkheadbox DNA-binding domain containing transcription factor required for proper development of speech and language, which are both inherited from the healthy mother (Table S3). Variants in CACNAIH have previously been identified in patients with ASD, however, they did not segregate with ASD phenotypes, suggesting that they are not causative alone, although they could contribute to the phenotype (Splawski et al. 2006). Mutations in FOXP2 cause developmental language disorders in humans (Lai et al. 2001). Their contribution to ASD has been extensively been studied (Gauthier et al. 2003; Newbury et al. 2002; Wassink et al. 2002). However, the presence of the missense variant in the healthy mother suggests that this variant is not sufficient to explain the phenotype of the brothers on its own but it could be part of the cause of their language impairment. Further studies are therefore needed to confirm the contribution of $S L C 7 A 3$ variants to ASD and apprehend the genetic interactions in individual cases.

\begin{abstract}
Acknowledgments The authors thank the patients for their participation in the study, the genotyping and sequencing platform of the ICM, Mélanie Marcos for technical assistance, the DNA and cell bank for DNA extraction and cell culture, the International Parkinson's Disease Genomics Consortium (IPDGC) and Aude Nicolas for giving access to the list of $S L C 7 A 3$ variants present in control populations. The authors thank the Exome Aggregation Consortium and the groups that provided exome variant data for comparison. A full list of contributing groups can be found at http://exac.broadinstitute.org/about. This study was funded by ANR ERANET EUHFAUTISM ANR10-NEUR-003-03/R11084DD, Fondation de France/R13024DD, INSERM, AP-HP, the program "Investissements d'avenir" ANR10-IAIHU-06 (IHU-A-ICM) and the German Research Foundation (DFG) grant Cl 100/4-3 to EIC. C.N., A.B. and C. De are members of Bio-Psy Labex.
\end{abstract}

\section{Compliance with ethical standards}

Conflict of interest The authors declare no competing interests.
Open Access This article is distributed under the terms of the Creative Commons Attribution 4.0 International License (http://creativecommons.org/licenses/by/4.0/), which permits unrestricted use, distribution, and reproduction in any medium, provided you give appropriate credit to the original author(s) and the source, provide a link to the Creative Commons license, and indicate if changes were made.

\section{References}

Amiet C, Gourfinkel-An I, Bouzamondo A, Tordjman S, Baulac M, Lechat P, Mottron L, Cohen D (2008) Epilepsy in autism is associated with intellectual disability and gender: evidence from a meta-analysis. Biol Psychiatry 64(7):577-582

Barrett S, Beck JC, Bernier R, Bisson E, Braun TA, Casavant TL, Childress D, Folstein SE, Garcia M, Gardiner MB, Gilman S, Haines JL, Hopkins K, Landa R, Meyer NH, Mullane JA, Nishimura DY, Palmer P, Piven J, Purdy J, Santangelo SL, Searby C, Sheffield V, Singleton J, Slager S et al (1999) An autosomal genomic screen for autism. Collaborative linkage study of autism. Am J Med Genet 88(6):609-615

Betancur C (2011) Etiological heterogeneity in autism spectrum disorders: more than 100 genetic and genomic disorders and still counting. Brain Res 1380:42-77

Beyer SR, Mallmann RT, Jaenecke I, Habermeier A, Boissel JP, Closs EI (2013) Identification of cysteine residues in human cationic amino acid transporter hCAT-2A that are targets for inhibition by N-ethylmaleimide. J Biol Chem 288(42):30411-30419

Bourgeron T (2009) A synaptic trek to autism. Curr Opin Neurobiol 19(2):231-234

Braissant O, Gotoh T, Loup M, Mori M, Bachmann C (1999) L-arginine uptake, the citrulline-NO cycle and arginase II in the rat brain: an in situ hybridization study. Brain Res Mol Brain Res 70(2):231-241

Bucan M, Abrahams BS, Wang K, Glessner JT, Herman EI, Sonnenblick LI, Alvarez Retuerto AI, Imielinski M, Hadley D, Bradfield JP, Kim C, Gidaya NB, Lindquist I, Hutman T, Sigman M, Kustanovich V, Lajonchere CM, Singleton A, Kim J, Wassink TH, McMahon WM, Owley T, Sweeney JA, Coon H, Nurnberger JI, Li M, Cantor RM, Minshew NJ, Sutcliffe JS, Cook EH, Dawson G, Buxbaum JD, Grant SF, Schellenberg GD, Geschwind DH, Hakonarson H (2009) Genome-wide analyses of exonic copy number variants in a family-based study point to novel autism susceptibility genes. PLoS Genet 5(6):e1000536

Chilian B, Abdollahpour H, Bierhals T, Haltrich I, Fekete G, Nagel I, Rosenberger G, Kutsche K (2013) Dysfunction of SHANK2 and CHRNA7 in a patient with intellectual disability and language impairment supports genetic epistasis of the two loci. Clin Genet 84(6):560-565

Closs EI (2002) Expression, regulation and function of carrier proteins for cationic amino acids. Curr Opin Nephrol Hypertens 11(1):99-107

Closs EI, Graf P, Habermeier A, Cunningham JM, Forstermann U (1997) Human cationic amino acid transporters hCAT-1, hCAT2A, and hCAT-2B: three related carriers with distinct transport properties. Biochemistry 36(21):6462-6468

Closs EI, Boissel JP, Habermeier A, Rotmann A (2006) Structure and function of cationic amino acid transporters (CATs). J Membr Biol 213(2):67-77

Depienne C, Moreno-De-Luca D, Heron D, Bouteiller D, Gennetier A, Delorme R, Chaste P, Siffroi JP, Chantot-Bastaraud S, Benyahia B, Trouillard O, Nygren G, Kopp S, Johansson M, Rastam M, Burglen L, Leguern E, Verloes A, Leboyer M, Brice A, Gillberg C, Betancur C (2009) Screening for genomic rearrangements and 
methylation abnormalities of the 15q11-q13 region in autism spectrum disorders. Biol Psychiatry 66(4):349-359

Ehninger D, Silva AJ (2011) Rapamycin for treating Tuberous sclerosis and Autism spectrum disorders. Trends Mol Med 17(2):78-87

Gauthier J, Joober R, Mottron L, Laurent S, Fuchs M, De Kimpe V, Rouleau GA (2003) Mutation screening of FOXP2 in individuals diagnosed with autistic disorder. Am J Med Genet A $118 \mathrm{a}(2): 172-175$

Gilman SR, Iossifov I, Levy D, Ronemus M, Wigler M, Vitkup D (2011) Rare de novo variants associated with autism implicate a large functional network of genes involved in formation and function of synapses. Neuron 70(5):898-907

Girirajan S, Dennis MY, Baker C, Malig M, Coe BP, Campbell CD, Mark K, Vu TH, Alkan C, Cheng Z, Biesecker LG, Bernier R, Eichler EE (2013) Refinement and discovery of new hotspots of copy-number variation associated with autism spectrum disorder. Am J Hum Genet 92(2):221-237

Glessner JT, Wang K, Cai G, Korvatska O, Kim CE, Wood S, Zhang $\mathrm{H}$, Estes A, Brune CW, Bradfield JP, Imielinski M, Frackelton EC, Reichert J, Crawford EL, Munson J, Sleiman PM, Chiavacci R, Annaiah K, Thomas K, Hou C, Glaberson W, Flory J, Otieno F, Garris M, Soorya L, Klei L, Piven J, Meyer KJ, Anagnostou E, Sakurai T, Game RM, Rudd DS, Zurawiecki D, McDougle CJ, Davis LK, Miller J, Posey DJ, Michaels S, Kolevzon A, Silverman JM, Bernier R, Levy SE, Schultz RT, Dawson G, Owley T, McMahon WM, Wassink TH, Sweeney JA, Nurnberger JI, Coon H, Sutcliffe JS, Minshew NJ, Grant SF, Bucan M, Cook EH, Buxbaum JD, Devlin B, Schellenberg GD, Hakonarson H (2009) Autism genome-wide copy number variation reveals ubiquitin and neuronal genes. Nature 459(7246):569-573

Hafezparast M, Ahmad-Annuar A, Wood NW, Tabrizi SJ, Fisher EM (2002) Mouse models for neurological disease. Lancet Neurol 1(4):215-224

Heil KM, Schaaf CP (2013) The genetics of Autism Spectrum Disorders-a guide for clinicians. Curr Psychiatry Rep 15(1):334

Hosokawa H, Sawamura T, Kobayashi S, Ninomiya H, Miwa S, Masaki T (1997) Cloning and characterization of a brain-specific cationic amino acid transporter. J Biol Chem 272(13):8717-8722

Hosokawa H, Ninomiya H, Sawamura T, Sugimoto Y, Ichikawa A, Fujiwara K, Masaki T (1999) Neuron-specific expression of cationic amino acid transporter 3 in the adult rat brain. Brain Res 838(1-2):158-165

Huang Y, Kang BN, Tian J, Liu Y, Luo HR, Hester L, Snyder SH (2007) The cationic amino acid transporters CAT1 and CAT3 mediate NMDA receptor activation-dependent changes in elaboration of neuronal processes via the mammalian target of rapamycin mTOR pathway. J Neurosci 27(3):449-458

Huguet G, Ey E, Bourgeron T (2013) The genetic landscapes of autism spectrum disorders. Annu Rev Genomics Hum Genet 14:191-213

Iossifov I, Ronemus M, Levy D, Wang Z, Hakker I, Rosenbaum J, Yamrom B, Lee YH, Narzisi G, Leotta A, Kendall J, Grabowska E, Ma B, Marks S, Rodgers L, Stepansky A, Troge J, Andrews P, Bekritsky M, Pradhan K, Ghiban E, Kramer M, Parla J, Demeter R, Fulton LL, Fulton RS, Magrini VJ, Ye K, Darnell JC, Darnell RB, Mardis ER, Wilson RK, Schatz MC, McCombie WR, Wigler M (2012) De novo gene disruptions in children on the autistic spectrum. Neuron 74(2):285-299

Iossifov I, O'Roak BJ, Sanders SJ, Ronemus M, Krumm N, Levy D, Stessman HA, Witherspoon KT, Vives L, Patterson KE, Smith JD, Paeper B, Nickerson DA, Dea J, Dong S, Gonzalez LE, Mandell JD, Mane SM, Murtha MT, Sullivan CA, Walker MF, Waqar Z, Wei L, Willsey AJ, Yamrom B, Lee YH, Grabowska E, Dalkic E, Wang Z, Marks S, Andrews P, Leotta A, Kendall J, Hakker I, Rosenbaum J, Ma B, Rodgers L, Troge J, Narzisi G, Yoon S, Schatz MC, Ye K, McCombie WR, Shendure J, Eichler EE, State
MW, Wigler M (2014) The contribution of de novo coding mutations to autism spectrum disorder. Nature 515(7526):216-221

Ito K, Groudine M (1997) A new member of the cationic amino acid transporter family is preferentially expressed in adult mouse brain. J Biol Chem 272(42):26780-26786

Jager K, Wolf S, Dobrowolny H, Steiner J, Nave H, Maronde E, Bogerts B, Bernstein HG (2013) Differential topochemistry of three cationic amino acid transporter proteins, hCAT1, hCAT2 and hCAT3, in the adult human brain. Amino Acids 44(2):423-433

Jeste SS, Geschwind DH (2014) Disentangling the heterogeneity of autism spectrum disorder through genetic findings. Nat Rev 10(2):74-81

Jiang YH, Sahoo T, Michaelis RC, Bercovich D, Bressler J, Kashork CD, Liu Q, Shaffer LG, Schroer RJ, Stockton DW, Spielman RS, Stevenson RE, Beaudet AL (2004) A mixed epigenetic/genetic model for oligogenic inheritance of autism with a limited role for UBE3A. Am J Med Genet A 131(1):1-10

Junaid MA, Pullarkat RK (2001) Proteomic approach for the elucidation of biological defects in autism. J Autism Dev Disord 31(6):557-560

Kidd T, Bland KS, Goodman CS (1999) Slit is the midline repellent for the robo receptor in Drosophila. Cell 96(6):785-794

Kim JW, Closs EI, Albritton LM, Cunningham JM (1991) Transport of cationic amino acids by the mouse ecotropic retrovirus receptor. Nature 352(6337):725-728

Krumm N, O'Roak BJ, Shendure J, Eichler EE (2014) A de novo convergence of autism genetics and molecular neuroscience. Trends Neurosci 37(2):95-105

Kumar RA, KaraMohamed S, Sudi J, Conrad DF, Brune C, Badner JA, Gilliam TC, Nowak NJ, Cook EH Jr, Dobyns WB, Christian SL (2008) Recurrent 16p11.2 microdeletions in autism. Hum Mol Genet 17(4):628-638

Lai CS, Fisher SE, Hurst JA, Vargha-Khadem F, Monaco AP (2001) A forkhead-domain gene is mutated in a severe speech and language disorder. Nature 413(6855):519-523

Lai MC, Lombardo MV, Baron-Cohen S (2014) Autism. Lancet 383(9920):896-910

Leblond CS, Heinrich J, Delorme R, Proepper C, Betancur C, Huguet G, Konyukh M, Chaste P, Ey E, Rastam M, Anckarsater H, Nygren G, Gillberg IC, Melke J, Toro R, Regnault B, Fauchereau F, Mercati O, Lemiere N, Skuse D, Poot M, Holt R, Monaco AP, Jarvela I, Kantojarvi K, Vanhala R, Curran S, Collier DA, Bolton P, Chiocchetti A, Klauck SM, Poustka F, Freitag CM, Waltes R, Kopp M, Duketis E, Bacchelli E, Minopoli F, Ruta L, Battaglia A, Mazzone L, Maestrini E, Sequeira AF, Oliveira B, Vicente A, Oliveira G, Pinto D, Scherer SW, Zelenika D, Delepine M, Lathrop M, Bonneau D, Guinchat V, Devillard F, Assouline B, Mouren MC, Leboyer M, Gillberg C, Boeckers TM, Bourgeron $\mathrm{T}$ (2012) Genetic and functional analyses of SHANK2 mutations suggest a multiple hit model of autism spectrum disorders. PLoS Genet 8(2):e1002521

Levy D, Ronemus M, Yamrom B, Lee YH, Leotta A, Kendall J, Marks S, Lakshmi B, Pai D, Ye K, Buja A, Krieger A, Yoon S, Troge J, Rodgers L, Iossifov I, Wigler M (2011) Rare de novo and transmitted copy-number variation in autistic spectrum disorders. Neuron 70(5):886-897

Murdoch JD, State MW (2013) Recent developments in the genetics of autism spectrum disorders. Curr Opin Genet Dev 23(3):310-315

Nava C, Dalle C, Rastetter A, Striano P, de Kovel CG, Nabbout R, Cances C, Ville D, Brilstra EH, Gobbi G, Raffo E, Bouteiller D, Marie Y, Trouillard O, Robbiano A, Keren B, Agher D, Roze E, Lesage S, Nicolas A, Brice A, Baulac M, Vogt C, El Hajj N, Schneider E, Suls A, Weckhuysen S, Gormley P, Lehesjoki AE, De Jonghe P, Helbig I, Baulac S, Zara F, Koeleman BP, Euro ERESC, Haaf T, LeGuern E, Depienne C (2014a) De novo 
mutations in HCN1 cause early infantile epileptic encephalopathy. Nat Genet 46(6):640-645

Nava C, Keren B, Mignot C, Rastetter A, Chantot-Bastaraud S, Faudet A, Fonteneau E, Amiet C, Laurent C, Jacquette A, Whalen S, Afenjar A, Perisse D, Doummar D, Dorison N, Leboyer M, Siffroi JP, Cohen D, Brice A, Heron D, Depienne C (2014b) Prospective diagnostic analysis of copy number variants using SNP microarrays in individuals with autism spectrum disorders. Eur J Hum Genet 22(1):71-78

Neale BM, Kou Y, Liu L, Ma'ayan A, Samocha KE, Sabo A, Lin CF, Stevens C, Wang LS, Makarov V, Polak P, Yoon S, Maguire J, Crawford EL, Campbell NG, Geller ET, Valladares O, Schafer C, Liu H, Zhao T, Cai G, Lihm J, Dannenfelser R, Jabado O, Peralta Z, Nagaswamy U, Muzny D, Reid JG, Newsham I, Wu Y, Lewis L, Han Y, Voight BF, Lim E, Rossin E, Kirby A, Flannick J, Fromer M, Shakir K, Fennell T, Garimella K, Banks E, Poplin R, Gabriel S, DePristo M, Wimbish JR, Boone BE, Levy SE, Betancur C, Sunyaev S, Boerwinkle E, Buxbaum JD, Cook EH Jr, Devlin B, Gibbs RA, Roeder K, Schellenberg GD, Sutcliffe JS, Daly MJ (2012) Patterns and rates of exonic de novo mutations in autism spectrum disorders. Nature 485(7397):242-245

Nelson RJ, Demas GE, Huang PL, Fishman MC, Dawson VL, Dawson TM, Snyder SH (1995) Behavioural abnormalities in male mice lacking neuronal nitric oxide synthase. Nature 378(6555):383-386

Newbury DF, Bonora E, Lamb JA, Fisher SE, Lai CS, Baird G, Jannoun L, Slonims V, Stott CM, Merricks MJ, Bolton PF, Bailey AJ, Monaco AP (2002) FOXP2 is not a major susceptibility gene for autism or specific language impairment. Am J Hum Genet 70(5):1318-1327

Nicholson B, Sawamura T, Masaki T, MacLeod CL (1998) Increased Cat3-mediated cationic amino acid transport functionally compensates in Cat1 knockout cell lines. J Biol Chem 273(24):14663-14666

O'Roak BJ, Deriziotis P, Lee C, Vives L, Schwartz JJ, Girirajan S, Karakoc E, Mackenzie AP, Ng SB, Baker C, Rieder MJ, Nickerson DA, Bernier R, Fisher SE, Shendure J, Eichler EE (2011) Exome sequencing in sporadic autism spectrum disorders identifies severe de novo mutations. Nat Genet 43(6):585-589

O'Roak BJ, Vives L, Girirajan S, Karakoc E, Krumm N, Coe BP, Levy R, Ko A, Lee C, Smith JD, Turner EH, Stanaway IB, Vernot B, Malig M, Baker C, Reilly B, Akey JM, Borenstein E, Rieder MJ, Nickerson DA, Bernier R, Shendure J, Eichler EE (2012) Sporadic autism exomes reveal a highly interconnected protein network of de novo mutations. Nature 485(7397):246-250

Perkins CP, Mar V, Shutter JR, del Castillo J, Danilenko DM, Medlock ES, Ponting IL, Graham M, Stark KL, Zuo Y, Cunningham JM, Bosselman RA (1997) Anemia and perinatal death result from loss of the murine ecotropic retrovirus receptor mCAT-1. Genes Dev 11(7):914-925

Pinto D, Pagnamenta AT, Klei L, Anney R, Merico D, Regan R, Conroy J, Magalhaes TR, Correia C, Abrahams BS, Almeida J, Bacchelli E, Bader GD, Bailey AJ, Baird G, Battaglia A, Berney T, Bolshakova N, Bolte S, Bolton PF, Bourgeron T, Brennan S, Brian J, Bryson SE, Carson AR, Casallo G, Casey J, Chung $\mathrm{BH}$, Cochrane L, Corsello C, Crawford EL, Crossett A, Cytrynbaum C, Dawson G, de Jonge M, Delorme R, Drmic I, Duketis E, Duque F, Estes A, Farrar P, Fernandez BA, Folstein SE, Fombonne E, Freitag CM, Gilbert J, Gillberg C, Glessner JT, Goldberg J, Green A, Green J, Guter SJ, Hakonarson H, Heron EA, Hill M, Holt R, Howe JL, Hughes G, Hus V, Igliozzi R, Kim C, Klauck SM, Kolevzon A, Korvatska O, Kustanovich V, Lajonchere CM, Lamb JA, Laskawiec M, Leboyer M, Le Couteur A, Leventhal BL, Lionel AC, Liu XQ, Lord C, Lotspeich L, Lund SC, Maestrini E, Mahoney W, Mantoulan C, Marshall CR, McConachie H, McDougle CJ, McGrath J, McMahon WM,
Merikangas A, Migita O, Minshew NJ, Mirza GK, Munson J, Nelson SF, Noakes C, Noor A, Nygren G, Oliveira G, Papanikolaou K, Parr JR, Parrini B, Paton T, Pickles A, Pilorge M, Piven J, Ponting CP, Posey DJ, Poustka A, Poustka F, Prasad A, Ragoussis J, Renshaw K, Rickaby J, Roberts W, Roeder K, Roge B, Rutter ML, Bierut LJ, Rice JP, Salt J, Sansom K, Sato D, Segurado R, Sequeira AF, Senman L, Shah N, Sheffield VC, Soorya L, Sousa I, Stein O, Sykes N, Stoppioni V, Strawbridge C, Tancredi R, Tansey K, Thiruvahindrapduram B, Thompson AP, Thomson S, Tryfon A, Tsiantis J, Van Engeland H, Vincent JB, Volkmar F, Wallace S, Wang K, Wang Z, Wassink TH, Webber C, Weksberg R, Wing K, Wittemeyer K, Wood S, Wu J, Yaspan BL, Zurawiecki D, Zwaigenbaum L, Buxbaum JD, Cantor RM, Cook EH, Coon H, Cuccaro ML, Devlin B, Ennis S, Gallagher L, Geschwind DH, Gill M, Haines JL, Hallmayer J, Miller J, Monaco AP, Nurnberger JI Jr, Paterson AD, Pericak-Vance MA, Schellenberg GD, Szatmari P, Vicente AM, Vieland VJ, Wijsman EM, Scherer SW, Sutcliffe JS, Betancur C (2010) Functional impact of global rare copy number variation in autism spectrum disorders. Nature 466(7304):368-372

Sanders SJ, Ercan-Sencicek AG, Hus V, Luo R, Murtha MT, MorenoDe-Luca D, Chu SH, Moreau MP, Gupta AR, Thomson SA, Mason CE, Bilguvar K, Celestino-Soper PB, Choi M, Crawford EL, Davis L, Wright NR, Dhodapkar RM, DiCola M, DiLullo NM, Fernandez TV, Fielding-Singh V, Fishman DO, Frahm S, Garagaloyan R, Goh GS, Kammela S, Klei L, Lowe JK, Lund SC, McGrew AD, Meyer KA, Moffat WJ, Murdoch JD, O'Roak BJ, Ober GT, Pottenger RS, Raubeson MJ, Song Y, Wang Q, Yaspan BL, Yu TW, Yurkiewicz IR, Beaudet AL, Cantor RM, Curland M, Grice DE, Gunel M, Lifton RP, Mane SM, Martin DM, Shaw CA, Sheldon M, Tischfield JA, Walsh CA, Morrow EM, Ledbetter DH, Fombonne E, Lord C, Martin CL, Brooks AI, Sutcliffe JS, Cook EH Jr, Geschwind D, Roeder K, Devlin B, State MW (2011) Multiple recurrent de novo CNVs, including duplications of the 7q11.23 Williams syndrome region, are strongly associated with autism. Neuron 70(5):863-885

Sanders SJ, Murtha MT, Gupta AR, Murdoch JD, Raubeson MJ, Willsey AJ, Ercan-Sencicek AG, DiLullo NM, Parikshak NN, Stein JL, Walker MF, Ober GT, Teran NA, Song Y, El-Fishawy P, Murtha RC, Choi M, Overton JD, Bjornson RD, Carriero NJ, Meyer KA, Bilguvar K, Mane SM, Sestan N, Lifton RP, Gunel M, Roeder K, Geschwind DH, Devlin B, State MW (2012) De novo mutations revealed by whole-exome sequencing are strongly associated with autism. Nature 485(7397):237-241

Schaaf CP, Sabo A, Sakai Y, Crosby J, Muzny D, Hawes A, Lewis L, Akbar H, Varghese R, Boerwinkle E, Gibbs RA, Zoghbi HY (2011) Oligogenic heterozygosity in individuals with high-functioning autism spectrum disorders. Hum Mol Genet 20(17):3366-3375

Schaafsma SM, Pfaff DW (2014) Etiologies underlying sex differences in Autism Spectrum Disorders. Front Neuroendocrinol 35(3):255-271

Splawski I, Yoo DS, Stotz SC, Cherry A, Clapham DE, Keating MT (2006) CACNA1H mutations in autism spectrum disorders. J Biol Chem 281(31):22085-22091

Srivastava AK, Schwartz CE (2014) Intellectual disability and autism spectrum disorders: causal genes and molecular mechanisms. Neurosci Biobehav Rev 46(Pt 2):161-174

Swiech L, Perycz M, Malik A, Jaworski J (2008) Role of mTOR in physiology and pathology of the nervous system. Biochim Biophys Acta 1784(1):116-132

Tanda K, Nishi A, Matsuo N, Nakanishi K, Yamasaki N, Sugimoto T, Toyama K, Takao K, Miyakawa T (2009) Abnormal social behavior, hyperactivity, impaired remote spatial memory, and increased D1-mediated dopaminergic signaling in neuronal nitric oxide synthase knockout mice. Mol Brain 2:19 
Tuchman R, Rapin I (2002) Epilepsy in autism. Lancet Neurol 1(6):352-358

Veenstra-VanderWeele J, Blakely RD (2012) Networking in autism: leveraging genetic, biomarker and model system findings in the search for new treatments. Neuropsychopharmacology 37(1):196-212

Vekony N, Wolf S, Boissel JP, Gnauert K, Closs EI (2001) Human cationic amino acid transporter hCAT-3 is preferentially expressed in peripheral tissues. Biochemistry 40(41):12387-12394

Veltman JA, Brunner HG (2010) Understanding variable expressivity in microdeletion syndromes. Nat Genet 42(3):192-193

Wassink TH, Piven J, Vieland VJ, Pietila J, Goedken RJ, Folstein SE, Sheffield VC (2002) Evaluation of FOXP2 as an autism susceptibility gene. Am J Med Genet 114(5):566-569
Weiss LA, Shen Y, Korn JM, Arking DE, Miller DT, Fossdal R, Saemundsen E, Stefansson H, Ferreira MA, Green T, Platt OS, Ruderfer DM, Walsh CA, Altshuler D, Chakravarti A, Tanzi RE, Stefansson K, Santangelo SL, Gusella JF, Sklar P, Wu BL, Daly MJ (2008) Association between microdeletion and microduplication at 16p11.2 and autism. N Engl J Med 358(7):667-675

Weitzdoerfer R, Hoeger H, Engidawork E, Engelmann M, Singewald N, Lubec G, Lubec B (2004) Neuronal nitric oxide synthase knock-out mice show impaired cognitive performance. Nitric Oxide Biol Chem 10(3):130-140

Werling DM, Geschwind DH (2013) Sex differences in autism spectrum disorders. Curr Opin Neurol 26(2):146-153 